$\xi=-$ 国

\title{
Analysis Contribution and Effectiveness of Local Taxes Toward Original Regional Income at Bandung City
}

\author{
Daniel Nababan ${ }^{1 *}$, Ivan Gumilar Sambas Putra \\ ${ }^{1}$ Faculty of Economic, Universitas Widyatama, Bandung, Indonesia \\ ${ }^{2}$ Faculty of Business Management, Universitas Widyatama, Bandung, Indonesia \\ *Corresponding author E-mail: daniel.nababan@widyatama.ac.id
}

\begin{abstract}
This research is done to analyze the magnitude of contribution and effectiveness of local taxes toward original regional income at Bandung City. Method that used is descriptive analysis. Analysis result show that contribution of local taxes has contribution toward original regional income. The higher contribution of local taxes in 2013 is $82,763 \%$ and the lower in 2010 is $68,671 \%$. Effectiveness of local taxes has effective toward original regional income. The higher effectiveness of local taxes in 2011 is $122,181 \%$ and the lower in 2016 is $78,210 \%$. The results of data analysis use SPSS Version 20 showed that the result of hypothesis testing partially is contribution of local taxes has impact toward original regional income, and effectiveness of local taxes has impact toward original regional income. The result of hypothesis.
\end{abstract}

Keywords: Contribution of Local Taxes; Effectiveness of Local Taxes and Original Regional Income.

\section{Introduction}

National development and regional development are carried out in order to improve the welfare and prosperity of the community, so that the success or failure of national development can be reflected in regional development. This is stated in [11], which reads 'promoting general welfare'. Because regional development is a reflection of national development, it is expected that the Regional Government (Pemda) together with the community can manage the potential of their regions to increase the level of economy and create new jobs. In improving the welfare of its people, the regional government must be able to maximize regional income. This is because one indicator of the success of a regional government is by maximizing locally-generated regional income [1]. In order for regional governments not to always depend on the central government, the regional government must be able to maximize locally-generated regional income (PAD). This is because locally-generated regional income is a large potential owned by Pemda in carrying out regional development [9]. In [14], stated that the locally-generated regional income consists of taxes, regional retribution, income from management of separated regional assets and other legitimate locally-generated regional income.

Based on the [8] concerning Regional Taxes, explains that types of taxes of which included in Bandung's local taxes are hotel taxes, restaurant taxes, entertainment taxes, advertisement taxes, street lighting taxes, parking taxes, underground water taxes, and the acquisition of land and building rights customs. The magnitude of regional taxes in locally-generated regional income of the city of Bandung in financing the development of Bandung City can be seen as follows.
Table 1: The role of regional taxes on locally-generated regional income of Bandung city

\begin{tabular}{|c|c|c|c|}
\hline Year & $\begin{array}{c}\text { Regional Taxes Reali- } \\
\text { sation }\end{array}$ & PAD Realisation & Percentage \\
\hline 2016 & 1.709 .807 .582 .556 & 2.152 .755 .704 .962 & $79,424 \%$ \\
\hline 2015 & 1.494 .147 .377 .053 & 1.859 .694 .643 .505 & $80,344 \%$ \\
\hline 2014 & 1.399 .598 .856 .917 & 1.716 .057 .298 .378 & $81,559 \%$ \\
\hline 2013 & 1.194 .087 .447 .016 & 1.442 .775 .238 .323 & $82,763 \%$ \\
\hline 2012 & 820.563 .651 .111 & 1.005 .583 .424 .429 & $81,601 \%$ \\
\hline 2011 & 667.106 .811 .687 & 833.254 .175 .288 & $80,060 \%$ \\
\hline 2010 & 302.378 .839 .983 & 440.331 .559 .083 & $68,671 \%$ \\
\hline
\end{tabular}

Table 2: The city of Bandung's regional taxes achievement

\begin{tabular}{|c|c|c|c|}
\hline Year & $\begin{array}{c}\text { Regional Taxes } \\
\text { Target }\end{array}$ & $\begin{array}{c}\text { Regional Taxes } \\
\text { Realisation }\end{array}$ & $\begin{array}{c}\% \text { of } \\
\text { Achievement }\end{array}$ \\
\hline 2016 & 2.186 .416 .770 .000 & 1.709 .807 .582 .556 & $78,201 \%$ \\
\hline 2015 & 1.598 .000 .000 .000 & 1.494 .147 .377 .053 & $93,501 \%$ \\
\hline 2014 & 1.400 .000 .000 .000 & 1.399 .598 .856 .917 & $99,971 \%$ \\
\hline 2013 & 1.407 .759 .106 .133 & 1.194 .087 .447 .016 & $84,822 \%$ \\
\hline 2012 & 727.000 .000 .000 & 820.563 .651 .111 & $112,870 \%$ \\
\hline 2011 & 546.000 .000 .000 & 667.106 .811 .687 & $122,181 \%$ \\
\hline 2010 & 291.800 .000 .000 & 302.378 .839 .983 & $103,625 \%$ \\
\hline
\end{tabular}

Based on Table 1 and 2, it can be seen that regional taxes have a very important role in PAD, which on average has a role of $79.203 \%$ of PAD. However, the magnitude of the role of regional taxes on PAD is not proportional to the achievement of regional taxes. The achievement of regional taxes has a tendency to decline with an average achievement of regional taxes of $99.310 \%$. 


\section{Literature Review}

\subsection{Regional autonomy}

According to [13] concerning Regional Government, regional autonomy is the right, authority and obligation of an autonomous region to regulate and manage their own government affairs and the interests of the local community in accordance with the legislation [13]. According to [5], there are three main missions in the implementation of regional autonomy and decentralization which are:

1. Improving the quality and quantity of public services and community welfare.

2. Creating efficiency and effectiveness in managing local resources.

3. Empower and create space for people to participate in the development process.

\subsection{Locally-generated Regional Income (PAD)}

According to [14], locally-generated regional incomes are incomes obtained from the regions from sources within their own territory and collected based on regional regulations in accordance with the applicable laws and regulations. Sources of locally-generated regional incomes consist of local taxes, regional retributions, income from management of separated regional assets and other legitimate locally-generated regional income.

\subsection{Regional tax}

According to [12], regional taxes are contributions to regional owed by private individuals and/or entities which are compulsory based on the law, in a way of not getting compensation directly and being used for regional needs for the greatest prosperity of the people.

Based on the [8] Concerning Regional Taxes, types of regional taxes are hotel taxes, restaurant taxes, entertainment taxes, advertisement taxes, street lighting taxes, parking taxes, groundwater taxes, land and building taxes, and the acquisition of land and building rights customs.

\subsection{Regional Tax Contribution}

Contribution is the amount of donations given for an activity carried out [7]. According to [10], the contribution of regional taxes is used to determine the extent to which regional taxes contribute to the receipt of locally-generated regional income. The greater the result means the greater the role of regional taxes on locallygenerated regional income, and vice versa [6]. Indicators of the contribution of regional taxes are the ratio between the realization of regional tax revenues and the realization of locally-generated regional income [4].

\subsection{Regional Tax Effectiveness}

Effectiveness is the relationship between outputs and goals or objectives that must be achieved. Effectiveness is related to achieving policy objectives or targets [5]. According to [4], the effectiveness of regional taxes is the ratio between regional tax collection and the potential tax returns.

\section{Methodology}

The research variables used in this study are as follows:

1. Dependent Variables (Y)

Dependent variable (Y) used in the study is PAD. According to [14] states that locally-generated regional income are incomes obtained from the regions from sources within their own territory which are collected based on regional regulations in accordance with the prevailing laws and regulations.
2. Independent Variable (X)

a. Regional Tax Contributions $\left(\mathrm{X}_{1}\right)$

According to [4], the indicator of Regional Tax Contributions is the ratio between the realization of regional taxes and the realization of locally-generated regional income. The contribution of regional taxes on locally-generated regional income can be calculated by the formula:

Contribution of Regional Tax

$=\frac{\text { Realization of Regional Taxes }}{\text { X } 100 \%}$

Realization of locally-generated regional income

To interpret the magnitude of the contribution of local taxes on local revenue, the following criteria are used:

Table 3: Classification of criteria for regional tax percentage contributions [2]

\begin{tabular}{|c|c|}
\hline Percentage & Criteria \\
\hline $0,00 \%-10 \%$ & Very Low \\
\hline $10,10 \%-20 \%$ & Low \\
\hline $20,10 \%-30 \%$ & Average \\
\hline $30,10 \%-40 \%$ & Above Average \\
\hline $40,10 \%-50 \%$ & High \\
\hline$>50 \%$ & Very High \\
\hline
\end{tabular}

b. Regional Tax Effectiveness (X2)

According to [4], the effectiveness of regional taxes is the ratio between regional tax collection and the potential of regional tax incomes. The indicator can be seen from the following formula:

Effectiveness of Regional Taxes

$=$ Regional Taxes Income Realization X $100 \%$

Regional Taxes Income Potential/Target

To interpret the magnitude of the effectiveness of regional tax income, the following criteria are used:

Table 4: Classification of criteria for regional taxes percentage effectiveness [2]

\begin{tabular}{|c|c|}
\hline Percentage & Criteria \\
\hline$>100 \%$ & Very Effective \\
\hline $90 \%-100 \%$ & Effective \\
\hline $80 \%-90 \%$ & Quite Effective \\
\hline $60 \%-80 \%$ & Less Effective \\
\hline$<60 \%$ & Not Effective \\
\hline
\end{tabular}

\section{Results and Discussion}

\subsection{Classic Assumption Test}

According to [3], testing the normality test was conducted to test whether the regression research has met the requirements of normal distribution and whether the residual variables in the regression model of the study have normal distribution. Following are the results of the normality test data:

Table 5: Normality Test

\begin{tabular}{|c|c|c|c|c|}
\hline \multicolumn{5}{|c|}{ One-Sample Kolmogorov-Smirnov Test } \\
\hline \multirow{2}{*}{\multicolumn{2}{|c|}{$\mathrm{N}$}} & PAD & ContriPD & EfectPD \\
\hline & & 7 & 7 & 7 \\
\hline \multirow{2}{*}{ Normal Parameters ${ }^{\mathrm{a}, \mathrm{b}}$} & Mean & ,99200 & ,79214 & 99314 \\
\hline & Std. Deviation &, 126494 & ,047747 &, 153701 \\
\hline \multirow{3}{*}{ Most Extreme Differences } & Absolute & 174 &, 373 & 113 \\
\hline & Positive & 108 & 226 & 113 \\
\hline & Negative &,- 174 &,- 373 &,- 097 \\
\hline \multicolumn{2}{|c|}{ Kolmogorov-Smirnov Z } & , 461 & ,986 &, 300 \\
\hline \multicolumn{2}{|c|}{ Asymp. Sig. (2-tailed) } & 984 & 285 & 1,000 \\
\hline \multicolumn{5}{|l|}{ Test distribution is normal. } \\
\hline
\end{tabular}


Based on Table 5, it can be seen that the value of asymptotic sig. (2-tailed) PAD of 0.984 , contribution of regional tax (ContriPD) of 0.285 and regional tax effectiveness (EFFPD) of 1,000 greater than 0.05 . So it can be concluded that the regression model of this research has a normal distribution.

\subsection{Multicollinearity Test}

Multicollinearity test was conducted to test the regression model if there is a correlation between independent variables, in which a good regression model should not have correlation between independent variables [3]. Following are the results of multicollinearity test data processing:

Table 6: Multicollinearity test

\begin{tabular}{|c|c|c|c|c|c|c|c|}
\hline \multicolumn{8}{|l|}{ Coefficients $^{\mathrm{a}}$} \\
\hline \multirow[t]{2}{*}{ Model } & \multicolumn{2}{|c|}{$\begin{array}{l}\text { Unstandardized } \\
\text { Coefficients }\end{array}$} & \multirow{2}{*}{$\begin{array}{c}\begin{array}{c}\text { Standardized } \\
\text { Coefficients }\end{array} \\
\text { Beta }\end{array}$} & \multirow[t]{2}{*}{$\mathrm{t}$} & \multirow[t]{2}{*}{ Sig. } & \multicolumn{2}{|c|}{$\begin{array}{l}\text { Collinearity } \\
\text { Statistics }\end{array}$} \\
\hline & B & \begin{tabular}{|c|} 
Std. \\
Error
\end{tabular} & & & & Tolerance & VIF \\
\hline (Constant) &, 372 & ,646 & & 7,57 & 096 & & \\
\hline 1 ContriPD & , 194 &, 058 &, 652 & 3,32 & 7,029 & ,986 & 1,015 \\
\hline EfectPD & ,686 & ,227 & ,833 & 3,02 & 039 & ,986 & 1,015 \\
\hline Depende & riabl & & & & & & \\
\hline
\end{tabular}

According to Table 6, it can be seen that the Tolerance and VIF values of each independent variable which are the contribution of regional taxes (ContriPD) and the effectiveness of regional taxes (EfectPD), are 0.986 and 1.015 respectively. So it can be concluded that multicollinearity did not occur in the regression model of this study.

\subsection{Autocorrelation Test}

According to [3], autocorrelation test is conducted to test whether there is a correlation in the linear regression model between confounding errors in period $t$ with period $t-1$ confounding errors, in which a good regression model is a regression that is free of autocorrelation. Following are the results of the autocorrelation test data:

Table 7: Autocorrelation Test

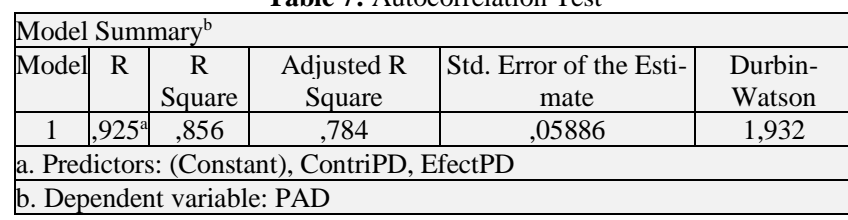

Based on Table 7, we can find that the Durbin Watson (DW) value of 1,932 , and du value of 1,896 . So that:

$\mathrm{du}<\mathrm{d}<4-\mathrm{du}$

$1,896<1,932<2,104$

So, we can make a conclusion that there is no autocorrelation in this regression model.

\subsection{Heteroscedasticity Test}

Heteroscedasticity testing conducted to test whether there is an inequality of variance in the regression from one observation to another observation, where a good regression research has no heteroscedasticity [3]. Here are the results of the heteroscedasticity test data:

\begin{tabular}{|c|c|c|c|c|c|}
\hline \multicolumn{6}{|l|}{ Coefficients ${ }^{\mathrm{a}}$} \\
\hline \multirow[t]{2}{*}{ Model } & \multicolumn{2}{|c|}{$\begin{array}{c}\text { Unstandardized Coeffi- } \\
\text { cients }\end{array}$} & $\begin{array}{c}\text { Standardized Coeffi- } \\
\text { cients }\end{array}$ & \multirow[t]{2}{*}{$\mathrm{T}$} & \multirow[t]{2}{*}{ Sig. } \\
\hline & B & $\begin{array}{l}\text { Std. } \\
\text { Error }\end{array}$ & Beta & & \\
\hline \begin{tabular}{l|l} 
Constant \\
\end{tabular} &, 117 & ,229 & & ,511 &, 636 \\
\hline$1 \longdiv { C o n t r i P D }$ & ,195 &, 259 & ,211 & ,754 &, 493 \\
\hline
\end{tabular}

\begin{tabular}{|l|c|c|c|c|c|c|}
\hline EfectPD &,- 224 &, 080 &,- 779 & - & 2,786 & 051 \\
\hline
\end{tabular}

Based on Table 8, it can be seen that the value of Sig. regional tax contribution (ContriPD) of 0.493 and Sig. regional tax effectiveness (EFFPD) of 0.051 is greater than 0.05 . So it can be concluded that in this regression model heteroscedasticity does not occur.

\subsection{Partial Hypothesis Test ( $t$ test)}

According to [3], $t$ test is testing the regression coefficients of each independent variable to the dependent variable to find out how much influence the independent variable has on the dependent variable. The following are the results of the partial test data $(t$ test):

Table 9: Partial Test (t Test)

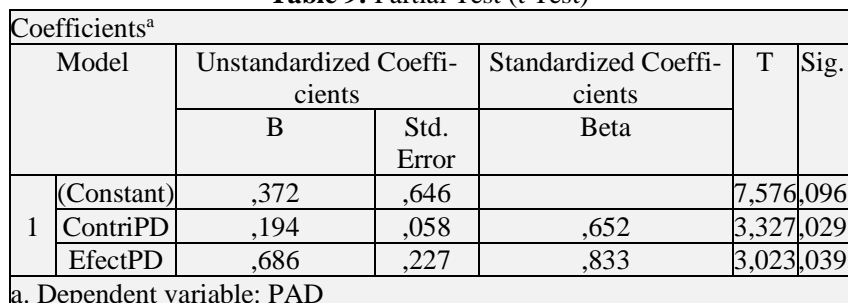

Based on Table 9, t-table value of 2.776 with a significance level $(\alpha)$ of 0.05 , the resulting hypothesis is as follows:

1. Hypothesis I (Variable Regional Tax Contribution / ContriPD)

It can be seen that the contribution of regional taxes (ContriPD) has a t-count of 3,327 and the value of Sig. amounting to 0.029 . This means that the $\mathrm{t}$-count value $>\mathrm{t}$-table $3.327>$ 2.776 and the value of Sig. $0.029<0.05$. So it can be concluded that $\mathrm{Ha}$ is accepted, which means the contribution of regional taxes (ContriPD) affecting the locally-generated regional income (PAD).

2. Hypothesis II (Variable Regional Tax Effectiveness / EffectPD)

It can be seen that the effectiveness of local tax (EFFPD) has a tcount of 3.023 and the value of Sig. amounting to 0.039. This means that $\mathrm{t}$-count $>\mathrm{t}$-table is $3.023>2.776$ and the value of Sig. $0.039<0.05$. So it can be concluded that the hypothesis that $\mathrm{Ha}$ is accepted, which means the effectiveness of regional taxes (EfectPD) affecting the locally-generated regional income (PAD).

\subsection{Simultaneous Hypothesis Test (Test F)}

According to [3], the F test is conducted to test whether all independent variables simultaneously influencing the dependent variable. Following are the results of the $\mathrm{F}$ test data processing:

Table 10: Simultaneous Test (F Test)

\begin{tabular}{|c|c|c|c|c|c|c|}
\hline \multicolumn{7}{|c|}{ ANOVA $^{\mathrm{a}}$} \\
\hline \multicolumn{2}{|r|}{ Model } & Sum of Squares & df & Mean Square & $\mathrm{F}$ & Sig. \\
\hline \multirow{3}{*}{1} & Regression & ,067 & 2 & 034 & 7,681 &, $040^{\mathrm{b}}$ \\
\hline & Residual & 029 & 4 & 007 & & \\
\hline & Total & ,096 & 6 & & & \\
\hline \multicolumn{7}{|c|}{ a. Dependent variable: PAD } \\
\hline & rs: $(\mathrm{C}$ & t), EfectPD, & 11 & & & \\
\hline
\end{tabular}

Based on Table 10, it can be seen that the calculated $\mathrm{F}$ value is 7.681 and the Sig value amounting to 0.040 . While, the F-table value is 6.94 and the value of Sig. Probability of 0.05 . This means that the calculated $F$ value $>$ F-table which is $7.681>6.94$ and the value of Sig. $0.040 \leq 0.05$. So it can be concluded that Ha is accepted, which means that independent variables which are the contribution of regional taxes (ContriPD) and the effectiveness of regional taxes (EfectPD) simultaneously influencing PAD. 


\section{Conclusion}

\subsection{Conclusion}

Based on the results of research and discussions that have been made regarding the contribution of local taxes and the effectiveness of local taxes on local revenue, it can be concluded that:

1. The highest realization of Bandung city's PAD was in 2016, which amounted to $\operatorname{Rp} 2,152,755,704,962$ and the lowest was in 2010, which amounted to Rp 440,331,559,083. While the highest PAD achievement occurred in 2011, which amounted to $115.732 \%$ and the lowest occurred in 2016 which was $77.790 \%$.

2. Based on a partial test (t test), it can be proved that the Contribution of Regional Taxes (ContriPD) from 2010-2016 has an effect on PAD of Bandung City. This means that the Contribution of Regional Taxes (ContriPD) in the locallygenerated regional income has an effect. Where the highest Regional Tax Contribution (ContriPD) occurred in 2013 which was $82.763 \%$ and the lowest occurred in 2010 which was $68.671 \%$.

3. Based on the partial test (t test), it can be proved that the Regional Tax Effectiveness (EfectPD) from 2010-2016 has an effect on the PAD of Bandung City. This means that the Regional Tax Effectiveness contributed to the Regional Original Income in the City of Bandung has an effect. Where the highest Regional Tax Effectiveness (EfectPD) occurred in 2011 that is equal to $122.181 \%$ and the lowest occurred in 2016 which was $78.201 \%$.

4. Based on the simultaneous test (F test), it can be proved that the Contribution of Regional Taxes (ContriPD) and Regional Tax Effectiveness (EfectPD) together influenced the PAD of Bandung City from 2010-2016.

\subsection{Recommendations}

Based on the results of research conducted on the contribution of regional taxes and the effectiveness of regional taxes the locallygenerated regional income in the city of Bandung, the researchers gave suggestions to the parties namely:

1. Regional Government of Bandung City

a. To increase regional taxes and explore potentials that are more detailed and adapted to the laws and regulations that apply in the Government of Bandung City.

b. Make efforts to intensify and extend regional taxes, so as to increase regional taxes and make a greater contribution to locally-generated regional income of the city of Bandung.

2. Next researcher

a. For the next researchers to be able to examine further about other factors that affect the locally-generated regional income of the city of Bandung.

b. By examining other factors that affect the locally-generated regional income of the city of Bandung, the researcher can then add more independent variables.

\section{References}

[1] Baihaqi, 2011, Analisis Kontribusi Pendapatan Asli Daerah Terhadap Pendapatan Daerah Provinsi Bengkulu. Jurnal Akuntansi, 1(3), 246-266.

[2] Departemen Dalam Negeri (Depdagri), Kemendagri Nomor 690.900.327 Tahun 1996.

[3] Ghozali, Imam, 2013, Analisis Multivariat dan Ekonometrika: Teori, Konsep dan Aplikasi SPSS 20. Unviersitas Diponegoro.

[4] Halim, Abdul, 2012, Akuntansi Sektor Publik: Akuntansi Keuangan Daerah. Salemba Empat.

[5] Mardiasmo, 2009, Akuntansi Sektor Publik. Penerbit Andi.

[6] Novita, Lam, \& Harijanto, Sabijono, 2015, Analisis Efektifitas Penerimaan Pajak Reklame Beserta Kontribusinya Terhadap
Pendapatan Asli Daerah Kota Manado. Jurnal EMBA, 3(2), 428437.

[7] Octovido, Irsandy, Nengah, Sudjana, \& Devi Farah, Azizah, 2014, Analisis Efektifitas dan Kontribusi Pajak Daerah Sebagai Sumber Pendapatan Asli Daerah Kota Batu. Jurnal Administrasi Bisnis, 15(1), 1-7.

[8] Peraturan Daerah (Perda) Kota Bandung Nomor 20 Tahun 2011 Tentang Pajak Daerah.

[9] Puspitasari, Elfayang Rizky Ayu, \& Abdul Rohman, 2014, Analisis Efektifitas, Efisiensi dan Kontribusi Pajak dan Retribusi Daerah Terhadap PAD Kabupaten Blora Tahun 2009-2013. Diponegoro Journal of Accounting, 2014, 133-147.

[10] Suswanti, Ari, 2017, Analisis Efektifitas dan Kontribusi Pajak Reklame Terhadap Pendapatan Asli Daerah Di Kota Bandung. Skripsi Fakultas Ekonomi, Universitas Widyatama.

[11] Undang-Undang Dasar 1945.

[12] Undang-Undang Republik Indonesia Nomor 28 Tahun 2009 Tentang Pajak Daerah dan Retribusi Daerah.

[13] Undang-Undang Republik Indonesia Nomor 32 Tahun 2004 Tentang Pemerintah Daerah.

[14] Undang-Undang Republik Indonesia Nomor 33 Tahun 2004 Tentang Perimbangan Keuangan Antara Pemerintah Pusat dan Pemerintah Daerah. 